\title{
GRAY'S AMBITION: PRINTED VOICES AND PERFORMING BARDS IN THE LATER POETRY
}

\section{BY JAMES MULHOLLAND}

Since Thomas Gray's "Elegy Written in a Country Church-yard" (1751) was central to the emergence of an English vernacular literary canon, it is easy to forget that Gray was also fascinated by oral cultures. ${ }^{1}$ Whether lodged in his rooms at Cambridge, researching in London at the British Museum, or traveling through Scotland and the Lake District, Gray collected notes and composed numerous essays about oral poetry and ancient and medieval bards in his three folio commonplace books. ${ }^{2}$ His interest in oral culture was more than scholarly; nearly all of his published poetry after the "Elegy" engaged with this research. "The Bard. A Pindaric Ode" (1757), for example, brims with intricate images of bards and revels in their prophetic voices, and the only new poems included in his final published volume, Poems of Mr. Gray (1768), were "imitations," as he called them, of Welsh and Scandinavian folk songs. ${ }^{3}$

Gray's focus on the figure of the bard and on oral cultures in general was not unusual; other mid-eighteenth-century authors were also studying oral culture, gradually re-characterizing it as impassioned and heroic rather than vulgar and corrupted. ${ }^{4}$ The bard figure took on a new seriousness as a result, and came to represent the proximity between oral performer and listener and the immediacy of face-to-face contact, particularly when set against the virtual, distanced relationship between author and reader increasingly engendered by print circulation. The bard was at the center of the separation and the subsequent imaginative reassessment of oral culture and print culture that occurred in mid-eighteenth-century Britain. Adopting (and adapting) the bard thus allowed Gray to reflect on the status of poetry and the changing significance of printed authorship. ${ }^{5}$

Recent critics have argued that Gray's interest in bards and oral cultures stemmed from his uneasiness about the literary marketplace and the public acclaim that accompanied the success of the "Elegy." Linda Zionkowski states, for instance, that by embracing older models of authorship Gray attempted to "recreate a pre-commercial past" as an alternative to the print marketplace, thereby rejecting the market's 
"ethos of productivity." Suvir Kaul observes that Gray's attraction to Welsh and Scandinavian bards was "a complex and overdetermined literary exercise" that imagined the "disenfranchised eighteenth-century poet ventriloquizing the voice of ancient cultural empowerment and finding in a feudal poetics a nostalgic celebration of bardic potency." According to these interpretations, imagining bards as secure, empowered, and respected poets eased the difficulty of negotiating between the desire for public literary authority and the aversion to market demands, concerns common to Gray's earlier poems like the "Sonnet on the Death of Mr. Richard West" (1742) and the "Elegy."

Though insightful, these accounts of Gray's relationship to oral culture do not explain why Gray, in allegedly trying to revive a "precommercial past" or recreate a "feudal poetics," repeatedly relied on commercial publication. If the goal was to escape the fetters of print by reverting to the inherently non-literate relationship between performer and listener that made oral culture so attractive, why did Gray persist in publishing poetry at all? This article argues that "The Bard" and his later imitations of Welsh and Scandinavian oral poetry, such as "The Fatal Sisters" (1768) and "The Triumphs of Owen. A Fragment” (1768), constitute an extended experiment through which Gray develops and refines a poetics of "printed voice." This experiment operates in two interrelated ways. Gray approximates in his poetry some of the formal characteristics of oral culture in order to foster a sense of immediacy between himself and his readers. Yet by inventing (and textualizing) a printed voice - an oral voice that enunciates (and is audible) as print-Gray simultaneously takes advantage of the possibilities for a wider audience that the dissemination of printed texts offers him.

In both "The Bard" and the imitations, Gray uses complex formal and editorial strategies to suggest the sense of vocal presence associated with oral performance. But after the public reacted negatively to esoteric elements of "The Bard," Gray modified his approach to printed voice. Whereas the Welsh voices in "The Bard" are internally qualified by a verse narrator, the bardic voices of Gray's imitations are presented on their own, framed only by a series of paratextual prefaces and annotations. These paratexts, by discriminating between Gray's editorial voice and the imitations' speakers, establish the opportunity - and the textual space-for bardic voices to appear without the kind of internal framing that exists in "The Bard." "With his imitations, then, Gray devises a literary form that he believes allows the reader to experience unadulterated bardic voices. Although most scholars view Gray's later poems as retreating into nostalgia for medieval modes of cultural authority 
or as simply appropriating the authenticity of marginalized figures, I suggest that he turns to oral cultures as a way to construct a poetic voice that speaks powerfully to particular audiences, as he felt bards once did, while simultaneously transcending the physical constraints of space and time in a way that can only be achieved through print. Rather than demonstrating his aversion to the literary marketplace, Gray's poetics of printed voice is a concerted attempt to reformulate the relationship between authors and readers.

\section{I. "A VOICE MORE THAN HUMAN": THE BARD IN MID-EIGHTEENTH-CENTURY BRITAIN}

Gray began to experiment with this new printed voice in his sweeping ode "The Bard." "The Bard" revives a tale—suspected then and subsequently disproved - that condemned the thirteenth-century English king Edward I for executing all the bards upon invading Wales. In Gray's poem, the last living Welsh bard alone confronts Edward's oncoming army. Started in the early 1750 s but not completed until 1757 , this poem signaled an important shift in Gray's career and turned attention toward traditional Scottish, Welsh, and Irish cultures, encouraging the collection of ancient ballads, folk songs, and runic poetry, an activity that became prominent during the $1760 \mathrm{~s}^{10}$

From its "Argument," it is immediately clear that this poem experiments with representing bardic voice. Here, Gray writes that the bard calls out to Edward with a "voice more than human . . . and with prophetic spirit declares, that all his cruelty shall never extinguish the noble ardour of poetic genius in the island ... and that men shall never be wanting . . . [to] boldly censure tyranny and oppression."11 The description of the bard censuring tyranny in a superhuman voice constructs a complex political allegory that connects Welsh resistance to English incursion with the preservation of Britain's poetic genius. By resisting the English invaders, the Welsh bards defend their political independence and their indigenous culture, the two essential attributes, in Gray's opinion, of poetic vibrancy. Succumbing to an English invasion means surrendering liberty and endangering poetry's very existence. The "Argument" of "The Bard" thus establishes a link between liberty and poetry that is secured by the bard, who had a political role in Welsh culture. ${ }^{12}$ From the poem's inception, then, Gray imagined that bardic voice was intimately involved in the perpetuation of liberty and poetry—or, at least, poetry in a distinctly non-English syntax and voice. But even as the bard calls out to condemn the English king, his speech is acknowledged to be futile. By representing the 
final utterances and ultimately the death of the last Welsh bard, Gray allegorizes in a single tragic instance the more gradual dissolution of the historical conditions that maintained bards as speakers firmly ensconced within the political structure.

Gray's uncertain relationship to the bards of this poem results from a conflicted desire for the public authority that he believed Welsh bards once possessed. It is widely accepted that Gray identifies with the last Welsh bard, a position that originated with statements attributed to him. In a written reminiscence, one of Gray's companions during the final years of his life, Norton Nicholls, recalls Gray saying, "I felt myself the Bard" while composing the poem. ${ }^{13}$ Some scholars have read this statement as a liberating moment in Gray's poetic development - the successful discovery of character and persona. ${ }^{14}$ Others have seen Gray's identification with the bard as the failure of his poetic voice. ${ }^{15}$ Still others have argued that Gray's fantasy of becoming a bard is part of a larger tendency of eighteenth-century English authors to "impersonate" bards and thus appropriate their voices imperialistically without respecting their specific cultural significance. ${ }^{16}$

However, when placed within the context of mid-eighteenth-century depictions of bards and within Gray's later career, it becomes clear that for Gray the figure of the bard signified an immediacy that printed poetry should aspire to, not an authentic voice that could compensate for the collapse of his own. No instance better illustrates the realignment of author and reader that Gray hoped printed voice could accomplish than his description of his encounter with John Parry, a Welsh musician who was popularly known as the "blind harper." ${ }^{17}$ At that time Gray had lost interest in his draft of the "The Bard," but after seeing Parry he felt inspired to complete the poem. Born in Wales in 1710, Parry was employed for the majority of his life by a prominent Welsh family, lived in London, and performed what Parry called "Antient Welsh airs" throughout England, where he was received as living confirmation of the existence of Welsh oral traditions. ${ }^{18}$ Parry traveled in 1757 to Cambridge where Gray saw him play. Gray reacted ecstatically to the performance, gushing in one letter that Parry "scratch'd out such ravishing blind Harmony, such tunes of a thousand year old with names enough to choak you, as have set all this learned body a'dancing" $(C, 2: 502) \cdot{ }^{19}$ Although Gray probably exaggerates when he describes the songs as "thousand year old" tunes, he is clearly inspired by the way that Parry's voice recalls historically distant Welsh art forms. He believed that through Parry's songs one could hear the past. Such a performance offered Gray an example of poetry that was embodied 
and immediate, and suggested a model for his ideal reading audience. Parry satisfied his listeners by providing them with a conception of Welsh history while pleasing their senses. (Anyone who could provoke the normally demure Gray to dance must have been pleasing indeed.) For Gray, this pleasure translated into renewed interest in "The Bard"; he comments approvingly that Parry's performance set his poem "in motion again" $(C, 2: 502)$. His choice of language is apt: after hearing Parry, Gray's body, his neglected poem, and his emergent poetics of printed voice are in motion.

Parry was not the only source for Gray's depiction of the Welsh bard, however, nor was Gray's imagination of this figure derived exclusively from Celtic sources. Gray claimed, for instance, that his models for the last bard also included Raphael's portrayal of God in Vision of Ezekiel (1518), and later added that Parmigianino's fresco in Italy's Santa Maria della Stecatta of Moses breaking the tablets was even "nearer to [his] meaning" than Raphael's painting [see figure 1$].{ }^{20}$ In both these artworks

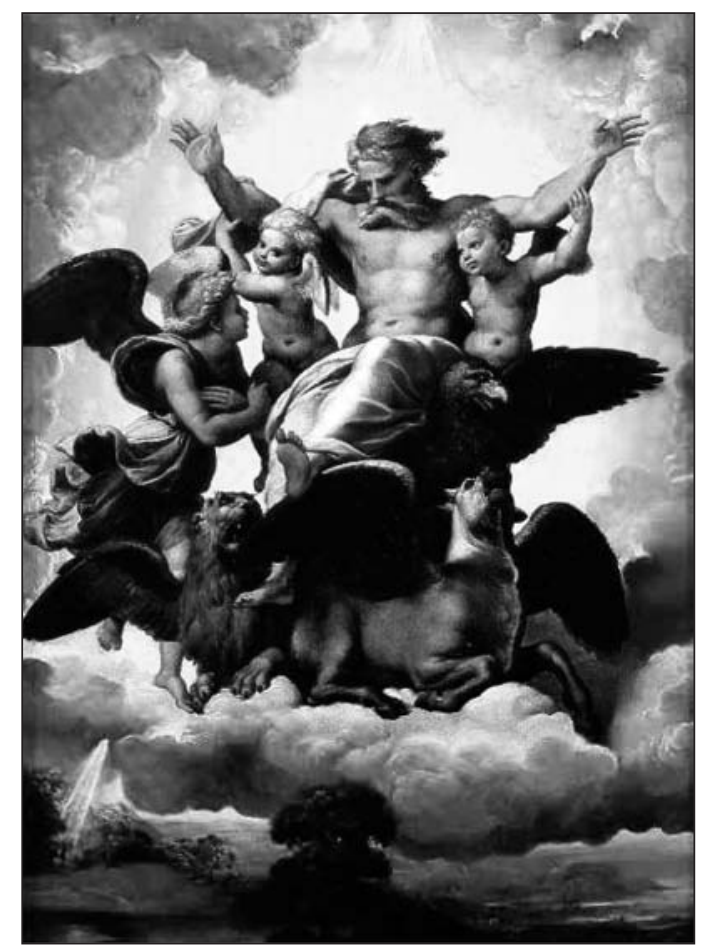

Figure 1. Raphael's Vision of Ezekiel (1518), one of the paintings that contributed to Gray's image of the last Welsh bard. 
Gray was attracted to the central figure's wild, uncouth looks-unruly hair, flowing beard-but one cannot discount their statuesque bodies, characteristic of Italian Renaissance painting. Perhaps most importantly, considering that Gray chose to compose "The Bard" as a modified Pindaric ode, both paintings represent Biblical scenes of prophets. Abraham Cowley, who revived the Pindaric ode for English literature during the seventeenth century, suggested a connection between the style of the Biblical prophets ("especially of Isaiah") and Pindar when he argued that both "pass from one thing to another with almost invisible connexions, and are full of words and expressions of highest and boldest flights of Poetry."21 Cowley's emphasis upon poetic flight accords with Raphael's depiction of God floating effortlessly among his heavenly host in Vision of Ezekiel, and Gray's interest in height and elevation, poetic and otherwise, is evident in him setting "The Bard" on Mount Snowdon, a dominant landmark and the highest point in Wales. Gray's imagination of the bard figure, therefore, is not wholly Celtic in the way that has been often assumed. In fact, he creates his own idiosyncratic image of the bard, and affirms Welsh oral culture by associating it with Greek poetry, the Bible, and Renaissance painting. Gray hopes to emphasize the kind of poetic effects such as the elevated tone and flights which Cowley describes as occurring in Pindar, which Raphael depicts in his painting, and which he feels while hearing Parry sing as much as he hopes to capture the authenticity of cultural situatedness that, scholars argue, bards signify at this historical moment.

\section{ENLARGING THE SMALL VOICE OF POETRY: WILDNESS AND WELSH PROSODY IN "THE BARD”}

The authority and poetic elevation that Gray grants bardic performance has little similarity to "the still small voice of Poetry," which he had claimed years earlier was not meant to be "heard in a crowd." Gray's lack of faith in English poetry's ability to reach an audience-his own included-was confirmed in 1748 with the release of Robert Dodsley's Collection of Poems. By Several Hands. ${ }^{22}$ Though Gray had been writing verse for years, Dodsley's volume contained his first publications, and he professed himself to be "ashamed" to see his work finally in print $(C, 1: 295)$. His shame derives from the feeling that his poetic voice, like that of his contemporaries and unlike those of bards, is weak and inaudible. His cynicism about this publication is an early instance of his belief that print circulation exacerbated this weakness.

This sense of shame and vulnerability is absent from "The Bard," particularly from the confident, exclamatory address of the first line: 
"'Ruin seize thee, ruthless King!" 23 Although the poem opens with the bard's voice in quotation marks, the identities of speaker and audience remain uncertain until the middle of the stanza. The speaker's anonymity makes it possible for his voice to invoke the collective power of "Cambria's curse," an effect which intensifies the stridency of the speech:

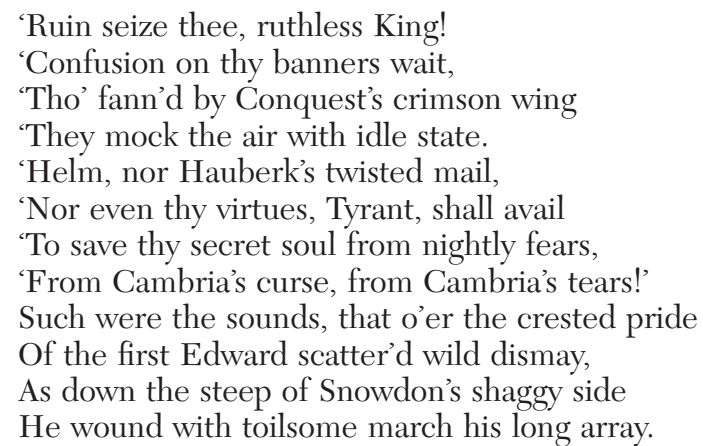

(“B," 1-12)

From the outset the bard's voice is prophetic, oracular, and accusatory, and Gray's description grants it a heightened poetic power not unlike the "highest and boldest" poetic flights that Cowley sees both in Pindar and the Bible. As the bard's "sounds" spill down upon Edward they seem to take on a life of their own, confronting the English army and scattering "wild dismay" over Edward's "crest'd" and thus perhaps already diminishing "pride." And as the poem proceeds, the importance of bardic voice only becomes more pronounced. Except for a single, quick utterance from one English captain, who simply says "To Arms!" ("B," 14), and the brief narration of the initial two stanzas and final two lines, the poem is cast in the voice of Welsh bards.

The collective presence implied by "Cambria's curse" takes on a new form near the middle of the poem. The poem's voices multiply as the last living Welsh bard is joined by some of his executed companions who have returned from the dead to avenge themselves upon their English oppressors. These ghostly bards' voices merge with that of the primary speaker, forming a supernatural choir whose intensified sound and dire predictions are described as "dreadful harmony":

'No more I weep. They do not sleep,

'On yonder cliffs, a griesly band,

'I see them sit, they linger yet,

'Avengers of their native land: 
'With me in dreadful harmony they join

'And weave with bloody hands the tissue of thy line.'

(“B," 43-48)

Using slant rhyme and internal rhyme Gray reproduces the double cadence that he claimed was central to Welsh oral poetry. ${ }^{24}$ This cadence, reflected in the combination of repeated sounds and caesurae in the lines "No more I weep. They do not sleep" and "I see them sit, they linger yet," amplifies the bardic harmony referred to in the above passage. "Double cadence," Gray writes in his commonplace book, arises from the "regular return of similar letters or syllables in the beginning or middle of a Verse," a technique, he feels, that is "very pleasing" for the listener. ${ }^{25}$ The natural melodies of oral poetry not only accentuate pleasure but also "assist the memory" by being both harmonious and strongly repeated throughout the composition. ${ }^{26}$ Although Gray relies on the systematic musicality and cultural function of Welsh verse, he also insists that the Welsh had not reduced its "harmony" to a rule but continued to "[practice] it wildly \& without art." ${ }^{27}$ The adaptation of Welsh verse, he hopes, will infuse "The Bard" with an atmosphere of wildness, maintain the emphasis upon history that allowed singers like Parry to recount "thousand year old" tunes, and harness its unique ability to be recalled. The attention to the musicality of prosody and oral mnemonics, moreover, resembles Gray's enthusiastic reaction to hearing Parry sing while at Cambridge. "The Bard," like Parry's performance, has the capacity to arouse the reader's senses while tantalizing the imagination because Welsh prosody is both "very pleasing" and evocative of Welsh history. By simulating the resonance of Welsh oral poetry, Gray constructs a printed voice that transcends the limitations that he believes makes contemporary English verse unable to be heard and remembered.

\section{VOICES OF THE FUTURE LOST IN THE PAST:}

ORAL PROPHECY, WEAVING, AND TYPOGRAPHY

Gray's awareness of rhythm and meter-and their ability to aid memory and communicate to listeners and readers - becomes explicitly thematized at those moments when he combines the poem's "double cadence" with the trope of weaving; the bards exclaim that they "weave with bloody hands the tissue of thy line" ("B," 48) and later that they "Weave the warp and weave the woof" ("B," 49) of their prophecy. These references to weaving, particularly "weav[ing] . . . lines," echo the alliteration and "double cadence" of the poem. The repetition of 
sounds interlaces individual lines together creating a verbal texture that is unified with the poem's subject matter-weaving occurs, that is, both in form and in content. It was Gray's research in Welsh prosody that led him to revive the use of alliteration, an unpopular literary device among eighteenth-century poets. Samuel Johnson declared that the use of alliteration in "The Bard" was "below the grandeur of a poem that endeavors to sublimity." ${ }^{28}$ Johnson, whose skepticism about oral traditions is well known, overlooks the fact that Gray's metrical experiments are part of an effort to recall aural forms and to facilitate a sense of connection like the one that exists between performer and listener. In a print culture that Gray perceived to be increasingly dominated by authors vulnerable to being misread, the intimacy made possible by textualizing a methodical yet presumably artless verse form structured through oral mnemonics must have appeared as an enticing alternative to the alienation of printed poetry.

What follows the bard's invocation of his deceased brethren is an elaborate history, imagined in the temporality of the poem as a prophecy, which recounts the tragedies of England until the ascension of the Tudors, who are seen as restoring native British rule to the island. To the bardic chorus, Edward and his descendents represent illegitimate political power, unlike the "long-lost Arthur" ("B," 109) and the other "genuine Kings" ("B," 110) of Britain's past. The chorus creates an opposition between Edward's genealogy ("line") that they have cursed with their song and the line of genuine monarchs that preceded Edward and that he violently usurped. The chorus celebrates these "genuine Kings" as "Britannia’s Issue" ("B," 110), an image that reinforces their legitimacy over Edward's bloody line. In this sense, "The Bard" combats Edward, and the political and aesthetic contamination that he represents not only with prophetic voice but with a poetic line that, like the bardic chorus, weaves the unfortunate fate of Edward and his descendents into a spoken curse. The form of the poem and its power to curse Edward are one and the same: the bard's prophecy-itself interwoven through the use of alliteration-is in fact English history which for Gray's readers had already come to pass.

The similarity of bardic song, lineal genealogy, and the lines of the poem expresses the particular kind of power that Gray collects by recasting the events of English history as the not-yet-enacted elements of prophecy. The unusual temporality of "The Bard"-where English history is transformed retroactively into Welsh prophecy-grants the Welsh bard a power that is accentuated by contemporary readers' collective acceptance of the history that he tells. In an odd way, then, Gray 
places the bard in a position to recognize another "line": the line of poets that make up England's literary inheritance. The bard states:

'A Voice, as of the Cherub-Choir,

'Gales from blooming Eden bear;

'And distant warblings lessen on my ear,

'That lost in long futurity expire.

(“B," 131-34)

The bard's song in this passage prefigures the devolved state of the English poetic tradition, which is depicted as lost, like a voice stretched to the greatest extent of its audibility. In a footnote to a later edition of this poem, Gray makes it clear that the cherubic voice that "gales" from "blooming Eden" is John Milton's, the "distant warblings" are the "long succession of poets" that follows him, and the "ear" that hears these voices belongs to the bard. ${ }^{29}$ Gray remarks that he did not intend his image of poetry's silence in "long futurity" to indicate that "Poetry in Britain was some time or other really to expire." He claims instead only to have meant that "it was lost from his [the bard's] ear from the immense distance" $(C, 2: 504)$. "The Bard" thus attempts to spatialize temporality, much as in the "Ode on the Distant Prospect of Eton College" (1742). But rather than looking into the past through memory, as in the "Eton College" ode the bard listens to the future, finding that his hearing begins to fail after Milton's voice. This transforms prophecy from a vision to be seen into a song to be heard, emanating from the future back into the past, which the Welsh bards in turn re-vocalize to Edward and his English army (as well as Gray's contemporary readers). By positioning the bard as an auditor of English authors' voices Gray implicitly suggests that they are less audible - in other words, less memorable - than their predecessors like Milton. The bards' prophecy thus comments on English poetry from a position outside of (and before) it.

The distinction between the relative audibility of English and Welsh and past and present voices is rendered even more precisely through the poem's formal properties. Rhetorical structure and typography differentiate the voices of "The Bard" and provide a guide, in tandem with point of view and stanza form, to their relative status and the relationships among them. Gray uses quotations marks to delineate the speakers of the poem - the verse narrator, the last Welsh bard, and the bardic chorus. He uses single quotation marks for the bard's voice and double quotation marks for the chorus, adding a single inverted comma to indicate the presence of extra voices [compare figures 2 and 
3]. This typographical change signals not only a transition between voices but also an integration of human and ghostly voices and an intensification of the resulting song. The highly self-conscious use of typography adds a material dimension to the voices of the poem and amplifies the idea that quotation marks disembody speech by representing it on the printed page thus distinguishing it from the rest of the text. ${ }^{30}$ All voices in a printed text are, by definition, disembodied. Quotation marks the living bard's voice and the bardic chorus whose utterances are doubly disembodied by being both cited and ghostly. But Gray employs quotation marks to suggest the material presence of the bard's speech and the supernatural audibility of the choir.

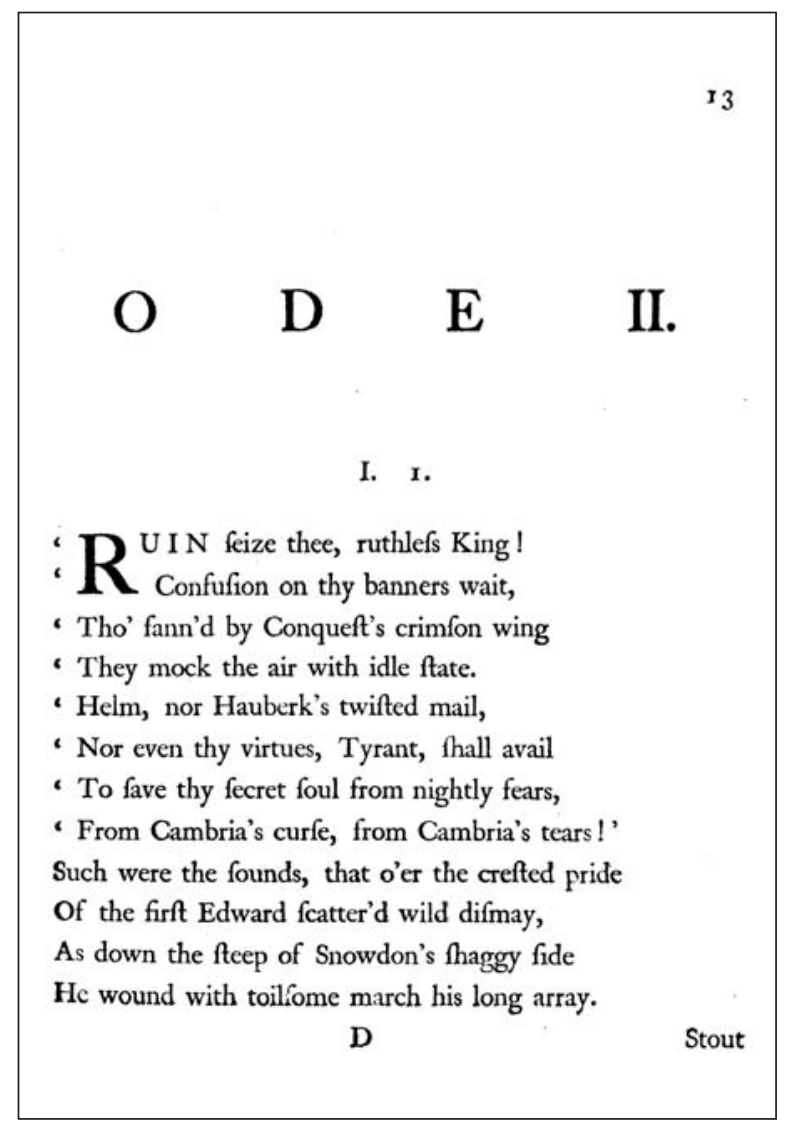

Figure 2. The first stanza of "The Bard" from 1757 when it was still simply titled "Ode II." The use of quotation marks ceases as the voice of the verse narrator appears. 


\section{O D E S}

- Brave Urien fleeps upon his craggy bed:

- Mountains, ye mourn in vain

- Modred, whofe magic fong

' Made huge Plinlimmon bow his cloud-top'd head.

' On dreary Arvon's Thore they lie,

' Smear'd with gore, and ghaftly pale:

' Far, far aloof th' affrighted ravens fail ;

' The famifh'd Eagle fcreams, and paffes by.

- Dear loft companions of my tuneful art,

' Dear, as the light, that vifits thefe fad eyes,

' Dear, as the ruddy drops that warm my heart,

' Ye died amidit your dying country's cries---_-_-

' No more I weep. They do not fleep.

' On yonder cliffs, a griefly band,

' I fee them fit, they linger yet,

' Avengers of their native land:

' With me in dreadful harmony they join,

' And weave with bloody hands the tiffue of thy lines.

II. $\mathbf{I}$.

" Weave the warp, and weave the woof,

" The winding-fheet of Edward's race.

" Give

Figure 3. The end of stanza 1.3 and the beginning of stanza 2.1 of "The Bard." Note that Gray shifts from single to double inverted commas as the single bard's voice is joined by those of his compatriots to form a bardic chorus.

The verse narrator's voice, however, never appears in quotation and thus in a sense remains unmarked - the basis from which the other voices of the poem should be distinguished. After the bard delivers the lengthy invective against Edward, for example, the poem's final two lines are pronounced by the verse narrator, who states: "He spoke, and headlong from the mountain's height / Deep in the roaring tide he plunged to endless night" ("B," 143-44). Most critics have focused on the bard's sudden suicide, but it is more significant that the poem concludes by re-emphasizing what should already be obvious about the 
bard: "He spoke." The poem, furthermore, ends not with the bard's song but with the verse narrator's description of his death. The past tense of the verse narrator's voice differs from the present or future tenses of the bards' voices, and shows that the verse narrator reflects on the events of the poem after they have occurred. Gray considered different endings for the poem but ultimately elected to place the verse narrator outside of the poem's dramatic action and distended temporality, permitting him to frame the bard's enunciations in much the same way that the quotation marks do. Printed voice cannot take advantage of obviously embodied, vocalized sounds as oral performance can. Instead, it must simulate presence, even individual presence, which requires a precise set of prosodic techniques and a typographical apparatus highly sensitive to different voices. In reproducing the structures of Welsh prosody and experimenting with typography, Gray makes poetic techniques, which are by definition disembodied, operate antithetically-that is, he makes them evoke embodiment and immediacy.

\section{IV. "VOCAL TO THE INTELLIGENT ALONE": \\ PRINTED DISSEMINATION AND THE IMPERSONATION OF BARDIC VOICE IN THE IMITATIONS}

Few of Gray's contemporary readers appreciated this attempt to textualize bardic voices because it involved unusual typographical techniques and metrical schemes that were associated with marginalized locales like Wales and with lower-class dialects. ${ }^{31}$ Although Gray had hoped to make bardic voice present and audible to his readers, many of his contemporaries took issue with what they felt was the poem's obscurity, a difficulty that they often figured as Gray's inarticulacy or unintelligibility. Upon hearing Gray read his ode aloud, one member of the audience was reported to have leaned over to a companion and asked if Gray was speaking in English, complaining that he could not understand a single word. ${ }^{32}$ Another reviewer dismissed the line "weave the warp and weave the woof"-in other words, Gray's approximation of Welsh metrics - as nothing more than "Spittle-fields poetry." 33 The Spitalfields area of London contained the majority of the English weaving industry and was densely populated with foreign immigrants, particularly Huguenots, most of whom spoke a type of French mixed with English phrases; as Maureen Waller writes, "in many of the streets of Spitalfields and Soho the immigrant population was so dense that it was rare to hear English spoken." "34 Hence, while humorously refracting the peculiar verbal texture of "The Bard," the 
reference to "Spittle-fields poetry" demonstrates that some readers, rather than being pleased by the poem, instead associated it with the vulgarity of working-class labor and the unintelligibility of immigrant French argots.

Gray reacted to these disparaging responses by questioning not his own articulacy but his readers' intellectual abilities. Before he had even completed his Odes, the collection in which "The Bard" first appeared, he confessed that it might exclude many readers:

[T] here is no Woman, that can take pleasure in this kind of composition. if Parts only \& imagination \& Sensibility were required, one might (I doubt not) find them in that Sex full as easily as our own: but there is a certain measure of learning necessary, \& long acquaintance with the good Writers, ancient \& modern, $w^{\text {ch }}$ by our injustice is denied to them. and without this they can only catch here \& there a florid expression, or a musical rhyme, while the Whole appears to them a wild obscure unedifying jumble. $(C, 2: 478)$

Gray was concerned that uneducated readers, whether men or women, would catch only a "florid expression" or a "musical rhyme"- that is, they would indulge in the immediate pleasures of orality and musicality without engaging the concomitant benefits of reason and learning. Interestingly, for educated readers Welsh metrics impart a "wild spirit," but for those who are not, Gray fears that it simply sounds like a "wild obscure unedifying jumble." 35 The wildness cultivated in "The Bard" thus is meant to be coupled with the learning that Gray so often finds lacking among English readers. Those with what Gray perceives to be a deficient education may misread — that is, mishear-the printed voice he devises in "The Bard."

The motto that appears on the title page of Gray's Odes in GreekGray later translated it as "vocal to the intelligent alone"-reinforces the sense that "The Bard" can only be understood by those readers who are well-versed in poetry and classical learning (C, 2:797). ${ }^{36}$ Gray admitted after the publication of his odes that he was surprised how few readers there were in England sufficiently "acquaint[ed] with the good Writers," insisting nonetheless that his "ambition terminated by that small circle" ( $C, 2: 797)$. However, upon hearing that a noted Italian critic had read and enjoyed his odes, he felt proud that "my voice has reach'd the ear and apprehension of a Stranger distinguish'd as one of the best Judges in Europe" $(C, 2: 797)$. The figuration of voice in these two instances - as intelligible only to a select few, yet able to traverse geographic boundaries and reach a distant, unknown reader's 
"ear"- demonstrates Gray's belief that the printed voice he develops in "The Bard" transcends the physical constraints of space and time but also speaks powerfully to particular readers in much the same way that Gray reacts to hearing Parry's songs. It is a voice that intermingles characteristics of both oral performance and printed dissemination, and the metaphors of audibility and intelligibility that Gray uses to describe this printed voice identify the type of audience and reaction that he imagines for his poems.

Bruised by the popular responses to his Odes, Gray promised angrily that "the next thing I print shall be in Welch. that's all" $(C, 2: 524)$. Although Gray's statement is undoubtedly meant to show some studied nonchalance about his public failure, in the next few years he partly fulfilled this promise: in $\mathbf{1 7 6 0}$ he began a series of loose translations of Norse and Welsh oral poetry which he called "imitations." Gray composed six imitations in total, though only three were published during his lifetime, in his 1768 Poems, which also included nearly all of his previously printed works. ${ }^{37}$

These imitations were initially inspired by research into ancient and medieval Celtic cultures that Gray undertook in 1759 at the British Museum. Gray intended them to appear in his widely anticipated but never completed History of English Poetry as a record "as far back as can be traced" of the poetry of the "Galic (or Celtic) nations" (C, 3:1123). Toward that end, the imitations use many of the rhetorical features (such as alliteration) that Gray thought originated with Celtic culture and that he began to explore in "The Bard." ${ }^{38}$ Creating these imitations was linguistically complex-Gray worked primarily from Latin translations, though he referred to transcriptions in the original language, whether Norse or Welsh, to decipher the metrical and aural qualities of the verse. ${ }^{39}$ The fidelity of his technique varies widely. Sometimes he follows the Latin texts closely while at other times he departs or even adds elements that do not appear in the originals or in the Latin. By calling these poems "imitations," Gray both unveils and obscures his role in their composition: imitation was widely understood to be the loosest form of translation, in which the author could both assert his or her presence and cancel it at the same time. ${ }^{40}$

Taken together, these imitations raise questions about what it means to be a printed author whose poems try to resemble the setting and conditions of oral poetry, and they represent another step in the experiment with printed voice Gray started in "The Bard." In these imitations, Gray presents bardic voices on their own rather than mediated through a verse narrator. Yet, due to the confusion which 
accompanied "The Bard," Gray frames the speakers of his imitations through prefaces and annotations that help make their voices intelligible by providing the kind of information that Gray complained many of his readers lacked. One imitation, for instance, is preceded by a two-page preface and another by an introduction that explains the voices and historical events presented in the poem. An overall "Advertisement," which divides Gray's imitations from the other works in his Poems, describes their evolution from Latin transcriptions into English texts. Gray also composed explanatory notes for the imitations, even if he claimed to do so "out of spite." 41 The mediation of bardic voices, rather than being internalized within the rhetorical structure of the poem, as it is in "The Bard," thus migrates out into the paratextual material that surrounds the individual imitations.

The added prefatory matter not only distinguishes the imitations from the other poems, but it also separates the editorial voice of the paratexts-which can be identified as Gray's-from the bardic voices of these imitations. The proliferation of paratexts, together with Gray's assertion that the imitations represent "specimens" of other nations" poetic heritage, craft a posture of disinterestedness and self-displacement. ${ }^{42}$ The origin of these poems, Gray suggests, lies in another culture's oral voices; his role as an editor and imitator is merely to present them to the reader. His depiction of himself as an imitator of others' initially oral compositions is intentionally simplified, of course, so as to convince the reader that they can actually hear bardic voices.

In the imitations, then, Gray creates the opportunity for readers to imagine that they experience bardic voices coming through the text. For example, "The Fatal Sisters," Gray's first imitation, which he completed in 1761, recounts an Icelandic legend of twelve sisters ("twelve gigantic figures resembling women") who sing while weaving human prophecy at their looms. ${ }^{43}$ The collective voice of the twelve women is never interrupted within the poem; instead, their voices are framed through a detailed preface that narrates how the poem ostensibly was disseminated by a curious "native" who overhears their song. ${ }^{44}$ The poem turns dramatically in the penultimate stanza when the sisters address this male interlocutor. They sing,

Mortal, thou that hear'st the tale,

Learn the tenour of our song.

Scotland, thro' each winding vale

Far and wide the notes prolong. ${ }^{45}$ 
It is through this listener, one critic argues, that the sisters' song is "heard, learned, and perpetuated . .. and passes into the historical and cultural vocabulary of Scotland." 46 This type of mediation is supposedly an imaginative attempt on Gray's part to contain the danger of powerful female voices, which are neutralized by the fact that the disseminator of their song is a man.

But the address to the male listener also fashions the poem's prehistory in oral circulation. Naturally, this kind of self-reflexivity about oral dissemination does not appear in the Norse song, or in the Latin transcription that Gray used to guide his imitation; the stanza is a versified instance of the scholarly tracing that Gray had hoped to accomplish in his aborted History of English Poetry. In actuality Gray does not search for the authentic origin of an oral tradition as much as he fabricates it. By fabricating this prehistory, he reduces, even obfuscates, his role in the composition of the poem: the extended transmission, of which the sisters sing, distances him from his role as author. Most reviewers shared this attitude, focusing upon the original documents and accepting Gray as merely a translator of them. ${ }^{47}$ Consequently, it is difficult to sustain the idea that the male auditor contains or neutralizes the sisters' voices; although it is his task to "prolong" their song, his voice, like Gray's, never appears in the poem and he learns the "tenour of our song" from the sisters, rather than vice versa. The mediation of the male interlocutor, therefore, is absorbed as a facet of the sisters' prophecy. They predict not only the political and historical events that supply the content of the poem but also their song's diffusion among the future inhabitants of Scotland. Thematizing the poem's origin in oral tradition further legitimizes Gray's decision about how to present the sisters' voices as print, and his text becomes an extension of their command to disseminate their song "far and wide."

Authorship also emerges as an issue in "The Triumphs of Owen. A Fragment," the last imitation that Gray composed, which presents the voice of a bard (complete with epic features such as epithets and kennings) celebrating the achievements of Owen, a twelfth-century Welsh prince. Gray refers to this poem as a fragment, accentuating his imagined role as an editor who has selected part of a text rather than as an author who has created it. Gray includes a preface for this poem, although it is shorter and less detailed than that of "The Fatal Sisters." Even though Gray knew this fragment was commonly attributed to the Welsh bard, Gwalchmai, its speaker remains unnamed, creating a sense of anonymous collective voice through which this tale presumably has survived and been transmitted. The absence of bibliographical 
detail suggests that Gray removed any marker of individual authorship, an action which accords with his choice to compose imitations in the first place. ${ }^{48}$ In "The Triumphs of Owen," however, his consciousness about authorship and fragmentation has great significance since this poem dramatizes its uneasy transition from sung utterance to literate object; in the first line, its speaker states that "Owen's praise demands my song," but the title refers to it as a "fragment," thereby highlighting its current, literary incarnation. ${ }^{49}$

Gray's figuration of himself as an editor and imitator of poems that ultimately originate in oral traditions is a crucial aspect of his printed voice after "The Bard." By reproducing bardic voices without any internal mediation, Gray forcefully distances himself from the voices on the page. In this fashion, what Katie Trumpener has called the "impersonation" of bardic voice becomes increasingly impersonal as Gray's experiment with printed voice shifts from the "The Bard" to the imitations. Gray's goal is not to decontextualize or fragment oral traditions and then absorb their authentic voices as his own, as Trumpener and others have claimed. On the contrary, he attempts to offer readers versions of medieval bardic voice unencumbered by interlocutors and mediation, at least within the body of the poem, thereby more effectively conjuring its oral cultural context. This context, recreated virtually within the bounded space of the printed imitation, is meant to replace the sense of disconnection Gray feels exists between modern authors and their readers with the sense of communicability that bards and their audience enjoyed during their oral performances: their voices travel through the text to the reader's ears, much as Gray's voice traveled to the critic that he believed to be one of the best judges in Europe.

\section{CONCLUSIONS}

Although many scholars consider Gray's imitations anomalous, and thus avoid discussing them, we misunderstand his ambition as an author if we see them as a product of his flagging literary power or as evidence of his withdrawal from the literary marketplace into simple nostalgia for medieval bardic culture. The ambiguous authorial/editorial stance of the imitations (implanted, as it is, within Gray's retrospective collection of his public poetry) and the complex textual spaces that Gray creates show that he continued to experiment with print and poetic voice until the end of his career, a fact that should alter our sense of him as an alienated author whose growing skepticism of the marketplace eventually led him to disengage entirely from it. 
Instead, Gray's repeated (and multifarious) representations of bardic voice as print were an attempt to develop an alternative to the prevailing author-reader relationship that the print culture of mid-eighteenth-century Britain was creating. Performers like Parry, who in Gray's mind was a modern-day bard, exemplified the desirable relationship to audience. Parry's performance was communal, immediate, and embodied, and Gray hoped to approximate these characteristics in his printed texts as a way to counter his sense of being disconnected from his readers. While Gray's invocations of bardic figures have important political ramifications and cannot be seen as innocent artistic gestures, for him these ramifications have as much to do with the perception that Celticism preserved political liberty, and thus guaranteed artistic vibrancy, as they do with the notion that he helped expand eighteenth-century British imperialism into a new aesthetic register. Gray's adoption of the bard does not necessarily imply the thoughtless appropriation of a marginalized culture's more authentic voice or sense of place. Rather, his image of the bard, as I have noted, originates not only in Celticism, but also in Renaissance paintings and the Bible. The emphasis upon Gray's role in the appropriation of marginalized voices has obscured the fact that the printed voice that Gray develops does not just borrow artistic techniques from other cultures but adapts them to new literary forms (like the Pindaric ode) and re-contextualizes them within the literary marketplace so as to simulate the immediacy that he increasingly felt print circulation destroyed.

This re-contextualization depends upon Gray's exploration of the possibilities and advantages offered by the literate text and by printed dissemination. As I have mentioned, Kaul describes Gray's imitations as a "complex and overdetermined literary exercise" about the disenfranchised poet "ventriloquizing the voice of ancient cultural empowerment" and recreating a "feudal poetics." I would emphasize more heavily what Kaul mentions in passing: the imitations (and "The Bard" as well) are a "literary exercise." Bardic voice is staged and enacted in writing, in print, and in instances of reading. The self-consciousness of Gray's literary devices, such as the use of typography to distinguish among speakers in "The Bard" or the inclusion of paratexts to frame the voices of his imitations, shows that the goal of his experiment is not to recreate an inherently oral "feudal poetics" or to revive a "precommercial past." Gray seeks to devise a printed voice that combines characteristics of oral traditional art forms with print's ability to make present, delineate, and widely disseminate different voices. He cultivates in his audience a relationship to reading texts that resembles 
listening to song, and asserts that the intimacy of oral performance can be achieved by readers who are specially attuned, through education, to his texts' aural possibilities. Constructing this kind of audience excludes some readers, of course, and clashes with the notion that bardic culture is, by definition, accessible to everyone. Even so, the communality and collectivity of printed voice is, for Gray, not an escape from the literary marketplace but a way to reform it. Gray's answer to the alienation that he encounters in the modern marketplace is to construct a circumscribed, highly knowledgeable readership that reacts to his printed works with the same sense of immediacy that he felt during Parry's performance at Cambridge. The knowing listener becomes Gray's model for the ideal reader.

Gray's experiment with printed voice in his later poems thus reveals a very different relationship to the literary marketplace and the capabilities of printed texts than that which is currently accepted in studies of Gray. Rather than retreating from poetry and escaping into fantasies of medieval culture, in "The Bard" and the imitations Gray reaches out to the growing constituency of eighteenth-century readers, whom scholars have too often believed only offended or embarrassed him, in an attempt to demonstrate that texts, by making bards' voices present, can please their senses and offer them an experience of the past. He continues to participate in the marketplace by imagining new ways for authors and readers to relate through texts. In many ways, then, my discussion of the poetics of printed voice in Gray's later poems is also an attempt to reveal that Gray is more optimistic about print and the literary marketplace, that most modern of eighteenth-century institutions, than we have believed him to be.

\section{Wheaton College, Massachusetts}

\section{NOTES}

Thanks to Michael McKeon, Paula McDowell, Marshall Brown, Joe Ponce, Hillary Chute, Rick Lee, and Natalie Phillips for reading earlier versions of this argument. Thanks also to the Daniel Francis Howard Travel Research Fellowship for support that helped me to complete this article.

${ }^{1}$ John Guillory argues in Cultural Capital: The Problem of Literary Canon Formation (Chicago: Univ. of Chicago Press, 1993) for Gray's centrality in the vernacular canon, reinforced by his importance in English grammar schools. Guillory writes that the context of Gray's "Elegy" is the "space time of vernacular literacy as that form of literacy is produced by the institutionalization of the vernacular canon in the primary schools of the eighteenth century" (87).

${ }^{2}$ For further information on Gray's scholarly interests, the best resource remains William Powell Jones, Thomas Gray, Scholar (Cambridge: Harvard Univ. Press, 1937). 
See also Robert L. Mack, Thomas Gray: A Life (New Haven: Yale Univ. Press, 2000), 531-90, for more on Gray's time at Cambridge and travels throughout Britain.

${ }^{3}$ Thomas Gray, Poems of Mr. Gray (London: J. Dodsley, 1768), 33.

${ }^{4}$ For two excellent synopses of this change, see Nicolas Hudson, "Oral Tradition: The Evolution of an Eighteenth-Century Concept," in Tradition in Transition: Women Writers, Marginal Texts, and the Eighteenth-Century Canon, ed. Alvaro Ribeiro and James G. Basker (New York: Oxford Univ. Press, 1996), 161-74; and "Constructing Oral Tradition: The Origins of the Concept in Enlightenment Intellectual Culture," in The Spoken Word: Oral Culture in Britain, 1500-1850, ed. Adam Fox and Daniel Wolff (Manchester: Manchester Univ. Press, 2001), 240-55. In the latter, Hudson argues that a significant re-evaluation of oral culture and language occurs during the mid eighteenth century.

${ }^{5}$ See Mark Booth, "Written and Writing Bards in Eighteenth-Century Lyric," $M L Q$ 53 (1992): 393-407. Booth excellently describes the resurgence of interest in bards during the mid eighteenth century but misunderstands their significance. He argues that bards were "timeless" and "ahistorical," and were inaccessible to authors because the "written is inaccessible to the oral" (403). As this article will show, Gray uses literate techniques to evoke the conditions of oral culture. For another argument on bards and voice, see Donald Wesling, "Difficulties of the Bardic: Literature and the Human Voice," Critical Inquiry 8 (1981): 69-81. My article seeks to counter his sense that "the bardic is print culture's nostalgia for oral culture" (73).

${ }^{6}$ Linda Zionkowski, Men's Work: Gender, Class, and the Professionalization of Poetry (New York: Palgrave, 2001), 155. These economic changes were expressed as authors' loss of status in the wider culture. She suggests that some, most notably Samuel Johnson, combatted this loss of status by instituting a gender ideology that sees involvement in the commercial marketplace of print as a reassertion of masculinity and cultural authority; see Zionkowski, 9-10. She writes that Gray, however, tried "to reclaim a cultural position for poets that would render them not marginal but central, not mercantile but heroic. And in so doing, he defined resistance to commerce, not participation in it, as the truly masculine stance for writers" (147).

${ }^{7}$ Suvir Kaul, Thomas Gray and Literary Authority: A Study in Ideology and Poetics (Stanford: Stanford Univ. Press, 1992), 239.

${ }^{8}$ I have borrowed the term "printed voice" from Eric Griffiths's The Printed Voice of Victorian Poetry (Oxford: Oxford Univ. Press, 1989). Griffiths argues that the "provision of voices for lines of print has to be done with every text" and that this is fundamentally an "exercise of imagination" (7). As he points out, the "poet's voice is not the voice of the person who is the poet," and the "voice is that which is decided in reading a text" (67). It is this act of "imaginative voicing" that turns readers into an audience (38).

${ }^{9}$ See Gérard Genette, Paratexts: Thresholds of Interpretation, trans. Jane E. Lewin (Cambridge: Cambridge Univ. Press, 1997), 1. Genette claims that the paratext is an "undefined zone between the inside and the outside, a zone without hard and fast boundary on either the inward side (turned toward the text) or the outward side (turned away from the text) . . . a zone not only of transition but also of transaction" (2). Genette also calls paratexts a "fringe" (2).

${ }^{10}$ Gray composed "The Bard" in fits and starts, and, as will be discussed shortly, he states that after abandoning the poem for some time he found the impetus to complete it after seeing John Parry perform Welsh songs in 1757. For a detailed history of the poem and its composition, see Poems of Thomas Gray, William Collins, and Oliver Goldsmith, ed. Roger Lonsdale (London: Longman, 1969), 177-83. 
${ }^{11}$ Thomas Gray, "Argument," in Poetic Commonplace Books and Manuscripts of Thomas Gray, 1716-1771 (Reading: Adams Matthews Publications, 1991), 932. The "Argument" was not published with the poem.

${ }^{12}$ Gray felt that bards occupied a public office that was conferred and fully sanctioned by the reigning political authority. See Roger Martin, Chronologie de la Vie et de L'Oeuvre de Thomas Gray (Paris: Les Presses Universitaires de France, 1931), 186. Gray's evidence derives from his research with medieval manuscripts that claim to describe accurately the role and function of medieval bards; for instance, that bards sat among Kings and Queens indicates, for Gray, their importance within the political structure.

${ }^{13}$ Norton Nicholl's includes these details in his "Reminiscenses" of Gray from 1805. See The Correspondence of Thomas Gray, ed. Paget Toynbee and Leonard Whibley, 3 vol. (Oxford: Clarendon Press, 1935), 3:1290. Hereafter abbreviated $C$ and cited parenthetically by volume and page.

${ }^{14}$ See Eugene McCarthy (Thomas Gray: The Progress of a Poet [Madison, NJ: Fairleigh Dickinson Univ. Press, 1997]), who writes that Gray's "poetic voice was liberated" after he assumed the "voice of the poet/bard" (229). Arthur Johnston claims that "The Bard" shows Gray "swinging" toward a concept of the poet that was "as far removed as possible from the figure he had represented in his earlier poems," and that through the bard Gray was "speaking in character" (Thomas Gray and the Bard [Cardiff, Wales: Univ. of Wales Press, 1966], 8, 9, 10). In The Poetry of Thomas Gray: Versions of the Self (Oxford: Oxford Univ. Press, 1973), Lonsdale argues that Gray escapes from himself by imagining himself as a bard, which is an instance of "total self-projection" (16). Howard Weinbrot considers "The Bard" to be Gray's affirmative departure from the private inspiriting muse of earlier poems (like the "Sonnet on West") in favor of the "public voice of nation" and a poet who, like the bard, evokes a unified community (Britannia's Issue: The Rise of British Literature from Dryden to Ossian [Cambridge: Cambridge Univ. Press, 1993], 385, 397).

${ }^{15}$ In Gray Agonistes: Thomas Gray and Masculine Friendship (Baltimore: Johns Hopkins Univ. Press, 1997), Robert F. Gleckner identifies the bard as Gray, though he sees this identification as the terminus of Gray's "Miltonic agon"- the culmination of Gray's struggle with Milton's continuous influence which, for Gleckner, also marks the tragic end of Gray's poetic career (90). His reading of the poem's conclusion, where the Bard hurls himself off Mount Snowdon to his death, says it all: "the Bard enacts in his plunge the willful sinking of Gray himself into the depths of eternal night and silence from which [he] will never be repaired nor his voice speak, much less sing" (92). Likewise, Wallace Jackson argues that Gray petitions voice, which "reflects the poet's uncertain claim to voice, [and that] his own poetry is vocal to a few . . . or to none" "Thomas Gray: Drowning in Human Voices?" Criticism 28 [1986]: 369; ellipsis in original). Gray's interest in bards is a "journey to voice" which Jackson feels is a characteristic response to "the initial malady of displaced voice from which all midcentury speaking seems to suffer" (369).

${ }^{16}$ Katie Trumpener, Bardic Nationalism: The Romantic Novel and the British Empire (Princeton: Princeton Univ. Press, 1997), 6. English poets, she argues, tried to "impersonate" bardic voice and to "imitate bardic materials" without an understanding of its cultural situatedness or its historical significance (6). Authentic bardic performance, she asserts, "binds the nation together across time and across social divides; it reanimates a national landscape made desolate first by conquest, then by modernization, infusing it with historical memory" (xii). She argues that this "re-functioning" of the bard by English 
authors like Gray simply displays "the nominalism of imperialism in a new, aesthetic register" (33). Trumpener is certainly right to point out the political ramifications of invoking the bard, but she overstates her case when she suggests that for Scottish and Irish antiquarians the bard represents "cultural situatedness" and the "expression of cultural practices and historical conditions" whereas for English "men of letters" the bard represents "cultural fragmentation and aesthetic autonomy" (xv).

${ }^{17}$ His blindness recalls not just the bard of James Thomson and David Mallet's Alfred: A Masque Represented before Their Royal Highnesses the Prince and Princess of Wales, at Clifden, On the First of August, 1740 (London, 1740) but also Homer and, more specifically, Thomas Blackwell's 1735 depiction of Homer as a blind ballad singer like Parry.

${ }^{18}$ Parry is best remembered now from Gray's comments about him in his letters. Parry was born in 1710 and died in 1782 . Blind at birth, he was a practicing harpist throughout his life and was patronized by the family of Sir Watkin Williams Wynn. He edited and published some of the earliest collections of Welsh music, including British Harmony, Being a Collection of Antient Welsh Airs, The Traditional Remains of those Originally Sung By the Bards of Wales, carefully compiled and now first published with some additional Variations, by John Parry (London, 1781). For more information on his life, see Anne Griffith, "Introduction," Four Lessons for Harp or Harpsichord by John Parry (Abergavenny, Gwent: Adlais, 1982), iv-vii; and Huw Williams, John Parry (1710?-1782): 'Y Telynor Dall,' The Blind Harper (Gwasnaeth Llyfrgell Clynd: Headquarters Library, County Civic Centre, Mold [Wales], 1982).

${ }^{19}$ The reference to "this learned body" is ambiguous. While it seems likely from the context that "this body" refers to Gray's body, it is also possible that "this body" could refer to the body of scholars at Cambridge, the audience of Parry's performance, of which Gray was a member.

${ }^{20}$ Gray writes: "the thought, $\mathrm{w}^{\mathrm{ch}}$ you applaud, in those lines, Loose his beard bc: is borrow'd from painting. Rafael in his Vision of Ezekiel (in the Duke of Orleans' Collection) has given the air of head, $w^{\text {ch }}$ I tried to express, To God the Father; or (if you have been at Parma) you may remember Moses breaking the Tables by the Parmeggiano, $\mathrm{w}^{\text {ch }}$ comes still nearer to my meaning" (Correspondence, 2:476-77 [27 August 1756]). He probably saw both of these art objects while touring Italy with Horace Walpole between 1739 and 1741. See Mack, 220-70.

${ }^{21}$ Abraham Cowley, The English Writings of Abraham Cowley, Volume 2: Poems: Miscellanies, The Mistress, Pindarique Odes, Davideis, Verses Written on Several Occasions (Cambridge: Cambridge University Press, 1905), 214.

${ }^{22}$ Gray's complete comment about Dodsley's Collection is: "You know I was of the publishing side, and thought your reasons against it none ... the still small voice of Poetry was not made to be heard in a crowd; yet Satire will be heard, for all her audience are by nature her friends" (Correspondence, 1:296). Gray's statement about poetry's "still small voice" alludes to a passage from 1 Kings 19:12 (KJV): "and after the earthquake a fire, but the Lord was not in the fire; and after the fire a still small voice."

${ }^{23}$ Gray, "The Bard," in Thomas Gray and William Collins: Poetical Works, ed. Lonsdale (Oxford: Oxford Univ. Press, 1977), line 1. Hereafter abbreviated "B" and cited parenthetically by line number.

${ }^{24}$ Gray's verse evokes elements of Welsh prosody, rather than replicates them exactly. See McCarthy, 194-201. From his recognition of the metrical patterns, however, McCarthy incorrectly argues that " $[\mathrm{t}] \mathrm{he}$ bards' and Gray's mission, voice, and authority appear identical” (201). 
${ }^{25}$ The term "double cadence" is Gray's, and he claims that double cadence is meant to suggest an affinity with a type of Welsh verse called Gorchest y Beirdh, which Gray translates as the "Excellent of the Bards" (Poetic Commonplace Books, 799). He writes in his commonplace book that Welsh compositions are "generally in stanzas regularly answering one another; \& there is a conceal'd harmony, arising from the regular return of similar letters or syllables in the beginning or middle of a Verse, doubtless very pleasing to ears accustom'd to the Cadence of their Poetry \& Language" (799). But Gray was partly mistaken in his understanding of Gorchest y Beirdh. As Johnston points out, this Welsh verse pattern was not formed until the fifteenth century, after the historical period in which "The Bard" is set. See Johnston, "Gray's Use of the Gorchest y Beirdd in "The Bard," Modern Language Review 59 (1964): 335-38.

${ }^{26}$ He felt that Welsh oral poetry was naturally melodic and thus enticing; at one point he writes that Welsh poems had "excellent Prosodia, \& $\mathrm{w}^{\text {ch }}$ is perhaps the finest, that any Language affords, [and] were admirably contrived for assisting the memory. they were all adapted to Musick, every word being harmonious, the strongest and most expressive repeated in a beautiful manner" (Poetic Commonplace Books, 799).

${ }^{27}$ Gray, Poetic Commonplace Books, 799.

${ }^{28}$ Samuel Johnson, The Lives of the Most Eminent English Poets; With Critical Observations on Their Works, 4 vol. (Oxford: Clarendon Press, 2006), 4:183.

${ }^{29}$ In the 1768 edition of this poem Gray added a footnote to the line "A Voice, as of the Cherub-Choir" that simply declared "Milton." This understated, seemingly self-explanatory footnote says a great deal about the importance and familiarity of Milton's "voice." Next to the "distant warblings" Gray included another footnote: "The succession of Poets after Milton's time" (Poetical Works, 199).

${ }^{30}$ See Marjorie Garber, Quotation Marks (New York: Routledge, 2003), 13-15, 19. These quotation marks, it should be noted, also appear in Gray's fair copy of the poem that he penned into his commonplace book. He was careful, therefore, that they appeared as well in the printed text.

${ }^{31}$ This resistance reflects the general response to his Odes (the collection where it first appeared) which was at once enthusiastic and confused. "The Bard" was one of two poems in Odes of Mr. Gray published in 1757. Jones gives a suitably complex assessment of the reading public's reception of Gray's volume when he says that though it might not have been universally appreciated, it was widely read; see Jones, "The Contemporary Reception of Gray’s Odes," Modern Philology 28 (1930): 61-82. To Gray's printer Robert Dodsley's great delight, the volume was also fairly widely bought: nearly twelve hundred of the initial two thousand that were printed had been purchased in the first two weeks. See Jones, "Contemporary Reception," 71.

${ }^{32}$ See Sylvester Douglas, The Diaries of Sylvester Douglas, Lord Glenbervie, ed. Francis Bickley 2 vol. (London: Constable and Co., 1928), 1:135.

33 "Odes of Mr. Gray," in Literary Magazine, or Universal Review II, 18 (1757): 422. The importance of Spitalfields grew after French Huguenots settled there during the 1700 s. With this influx of foreign labor, it was converted from open or cultivated fields into tenement housing for silk-weavers, an industry that came to dominate the area. Scholars estimate that there were between forty and fifty thousand workers involved in the silk trade in the early eighteenth century, mostly in London. For more, see Francis Sheppard, London: A History (Oxford: Oxford Univ. Press, 1998), 129, 172, 230; Christopher Hibbert, London: The Biography of a City (London: Penguin, 1969), 122; Stephen Inwood, A History of London (London: Macmillian, 1998), 332-33; and John Richardson, London and its People: A Social History from Medieval Times to the Present Day (London: Barrie and Jenkins, 1995), 152. 
${ }^{34}$ Maureen Waller, 1700: Scenes from London Life (New York: Four Walls Eight Windows, 2000), 271. Waller's evidence consists of the records of the French Huguenots who made up most of the population of Spitalfields. She notes that they still spoke and wrote in French, or a combination of French and English that Frenchified English words: one silk-weaver, for example, wrote his address as "dans la rue Lyon Rouge, paroisse Stepney, Spitlefeilds hameau" (271). These populations were not fully assimilated until three or four generations had passed; see Waller, 274.

${ }^{35}$ Gray claims in a handwritten note to his personal copy of the Odes that Welsh metrics convey a "wild spirit." See Lonsdale's note in Poems, 188.

${ }^{36}$ Gray selected this motto from Pindar's Olympian Odes. For more information about Pindar's odes and its role in Gray's poetry, see Lonsdale's introduction to "The Bard," in Poems, 157; and McCarthy, 167.

${ }^{37}$ This edition was published simultaneously in London and Glasgow, an unusual event for its time. Gray provided detailed instructions about how the volume was to be constructed, how his poems were to be presented, and in what order they would appear, further evidence that he remained interested in and involved with his printed works until the end of his life. He instructed his printers to place the three imitations near the end of the book, and remarked to Walpole that his Poems provided him with a sense of an ending, noting sardonically: "What has one to do, when turned of fifty, but really to think of finishing" (Correspondence, 3:1018 [February 25, 1768]).

${ }^{38}$ See Jones, Thomas Gray, Scholar, 102.

${ }^{39}$ Although the evidence is not conclusive, it seems that Gray could not read old Welsh or Old Norse, the languages of the originals, and hence relied almost exclusively on the Latin translations. Most scholars agree, however, that Gray had some small knowledge of the languages, particularly their rhythms, which he capitalized on when he devised the metrical forms of his imitations, as he did in "The Bard." For considerations of Gray's knowledge of Norse or Welsh, see Edward D. Snyder, The Celtic Revival in English Literature, 1760-1800 (Cambridge: Harvard Univ. Press, 1923), 34; Herbert W. Starr and J. R. Hendrickson, The Complete Poems of Thomas Gray; English, Latin and Greek (Oxford: Clarendon Press: 1966), x; G. L. Kittredge, "Gray's Knowledge of Old Norse," in Selections from the Poetry and Prose of Thomas Gray, ed. William Lyon Phelps (Boston: Ginn and Co., 1894), xli-l; and Jones, Thomas Gray, Scholar, 98-99, 101.

${ }^{40}$ For more on ideas about translation in the late seventeenth and early eighteenth century, see Judith Sloman, Dryden: The Poetics of Translation (Toronto: Univ. of Toronto Press, 1985).

${ }^{41}$ Gray made this comment about adding notes to "The Bard" in particular. His claimed to be spiteful toward his readers because he felt that the facts that make up the bards' prophecy could be found in any "six-penny History of England" (Correspondence, 3:1002 [1 February 1768]).

${ }^{42}$ In the overall "Advertisement" for the imitations, Gray explains that they were meant to be "some specimens of the Style that reigned in ancient times among the neighbouring nations ... and were our Progenitors" (Poems of Mr. Gray, 33).

${ }^{43}$ Gray, preface to "The Fatal Sisters," in Poetical Works, page 63. For complete information about "The Fatal Sisters," see Lonsdale, Poems, 210-13. "The Fatal Sisters," first titled by Gray "The Song of the Valkyries," was an Icelandic legend Davraðer Lioð from the eleventh century. Gray translated from Bartolin's Antiquitatum Danicum de Causis Contemptae Mortis, a volume of Norse poems with Latin translations which was published in Copenhagen in 1689. 
${ }^{44}$ Gray, preface to "The Fatal Sisters," in Poetical Works, page 63.

${ }^{45}$ Gray, "The Fatal Sisters," in Poetical Works, lines 57-60.

${ }^{46}$ Kaul, 241.

${ }^{47}$ See Stuart A. Millner, Thomas Gray's Welsh and Norse Poetry, unpub. diss. (1971), 80. In his discussion he refers particularly to contemporary reviews of Gray's later poetry in Critical Review 25 (1768): 367; and in Monthly Review, May 1768, 408.

${ }^{48}$ Gray's invocation of fragmentation was neither unprecedented nor a consequence of his inability to complete the imitation, as some have claimed. Johnston argues, for example, that Gray must have felt that an appropriate ending eluded him because Gray would never have deliberately published an unfinished poem as a fragment. See Johnston, "Gray's 'The Triumphs of Owen," Review of English Studies 11 (1960): 275-85, esp. 284. But Gray had suggested that an earlier poem ("A Long Story") was a fragment, noting at one point in the course of that poem: "(Here 500 stanzas are lost)." The mock-heroic tone of "A Long Story" no doubt shows that Gray was quite conscious of his editorial stance when he created what he called "fragments" (Poetical Works, 141).

${ }^{49}$ Gray, "The Triumphs of Owen," in Poetical Works, line 1. 